
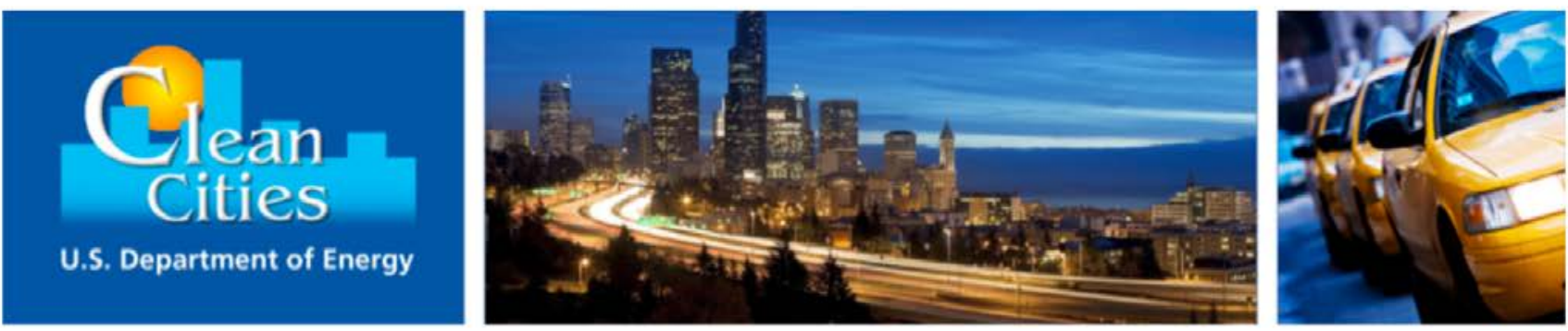

\title{
Clean Cities Niche Market Overview: Refuse Haulers
}

By Shannon Shea, U.S. Department of Energy

September 2011

DOE/GO-102011-3297 


\section{Clean Cities Niche Market Overview: Refuse Haulers}

Many niche market fleets, which operate specially designed vehicles that serve very specific functions, are ideal for the adoption of alternative fuels and advanced vehicle technologies. One prime example is the refuse hauler sector, whose 136,000 trucks average only 2.8 miles per gallon, ${ }^{1}$ using more than 1.2 billion gallons of fuel annually in the United States. This sector could substantially decrease its petroleum consumption through the use of alternative fuel or advanced technology vehicles. Before adopting these technologies, a refuse hauler fleet should consider both the technologies' benefits and the fleet's individual needs.

\section{Why use alternative fuels or advanced technologies?}

Alternative fuels and advanced vehicle technologies offer fleets the opportunity to decrease their petroleum consumption and increase their environmental and social sustainability. These fuels and

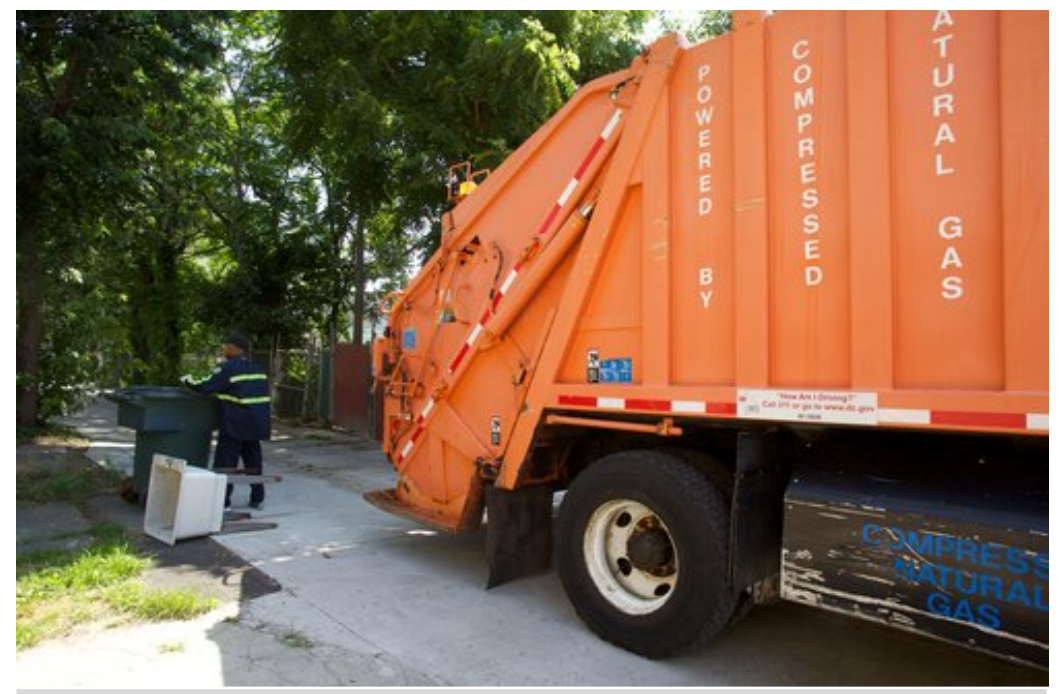

A refuse truck in Washington, D.C., powered by compressed natural gas. Using alternative fuels in urban areas can have significant air quality benefits.

Photo by Kaye Evans, PR Newswire, NREL/PIX 18249

technologies produce lower

levels of smog-forming

emissions, an important issue for trucks that often operate in urban areas with high asthma rates. Shifting away from petroleum-based fuels like gasoline and diesel can also result in lower greenhouse gas (GHG) emissions, reducing the refuse-collection sector's contribution to climate change.

Adopting alternative fuels and advanced vehicle technologies can help fleets fulfill requirements or offer a company a competitive advantage over others. Many city-owned fleets, such as the New York City Department of Sanitation, have adopted such measures in order to help meet the city's air quality and climate change goals. Some cities that contract out their garbage pickup will only contract companies that use these technologies. The vehicles can also offer substantial public relations opportunities. "It shows we're serious about being good stewards of the environment - that we are not afraid to put our money where our mouth is," says Peter Vanderhoof of Casella Waste, a Vermont refuse and recycling company. Some technologies can save fleets money over a vehicle's lifetime.

\footnotetext{
${ }^{1}$ INFORM. Greening Garbage Trucks: Trends in Alternative Fuel Use, 2002-2005.
} 


\section{Natural Gas}

Types of Natural Gas Vehicles

Compressed natural gas $(\mathrm{CNG})$ is one alternative fuel choice for refuse haulers, with more than 1,000 vehicles running on it in 2005. CNG, a domestically produced fuel, is gas (predominantly methane) stored at high pressure. It is nontoxic, odorless, noncorrosive, and produces $21 \%$ to $26 \%$ lower GHG emissions than diesel does. ${ }^{2} \mathrm{CNG}$ engines are somewhat less efficient than diesel engines are. ${ }^{3}$ However, CNG fuel prices are historically lower and more consistent than diesel, protecting fleets from unpredictable fuel price spikes. Some CNG fleets report saving money by

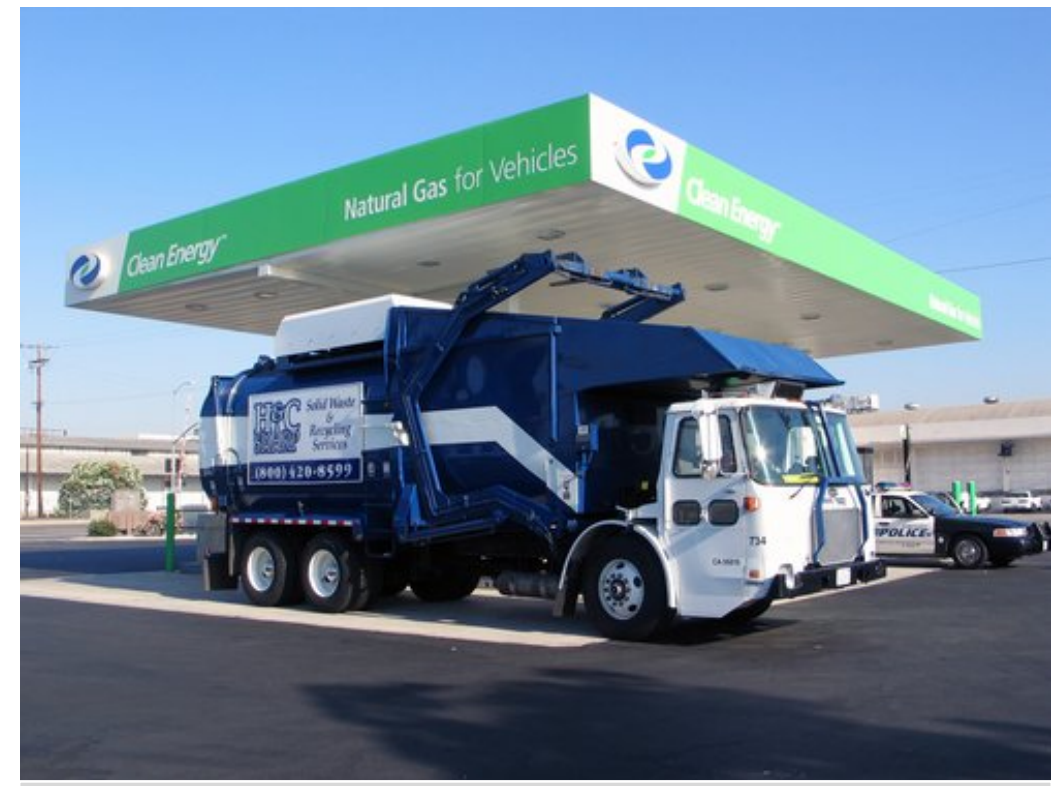

A refuse truck in California fueling up with CNG, which is domestically produced and results in lower levels of greenhouse gas emissions than diesel fuel does. Photo from Clean Energy, NREL/PIX 16724

fueling with $\mathrm{CNG}$, and some

report longer vehicle service lives. In addition, $\mathrm{CNG}$ vehicles produce lower levels of strongsmelling fumes and are $50 \%$ to $90 \%$ quieter than diesel vehicles, important for operations in residential areas. Centralized refueling with $\mathrm{CNG}$ can also be very practical for refuse fleets since they tend to travel on fixed routes and return to a home base for daily service and fueling. In some cases, CNG fueling is available near landfills.

For fleets interested in using natural gas, the National Renewable Energy Laboratory (NREL) has published the "Business Case for Compressed Natural Gas in Municipal Fleets." This report describes how an example refuse hauler fleet using CNG in more than 30 vehicles will have a payback period of less than seven years. Even fleets of only 14 trucks will reach a lifetime "break even" point. In general, larger fleets that drive more miles will have a shorter payback period and are more resilient to changes in costs.

Liquefied natural gas (LNG) is an option for refuse hauler fleets that need more fuel in a smaller space. LNG is natural gas cooled to liquid by lowering its temperature to -260 degrees

Fahrenheit. The liquid, which occupies only 1/600 of the volume of natural gas in vapor form, is

\footnotetext{
${ }^{2}$ Alternative Fuels and Advanced Vehicles Data Center (http://www.afdc.energy.gov/afdc/vehicles/emissions_natural_gas.html).

${ }^{3}$ NREL. Business Case for Compressed Natural Gas in Municipal Fleets.
} 
stored in double-wall, vacuum-insulated, pressurized vessels. Although most LNG vehicles are spark-ignition, technology has been developed that uses a compression-ignition cycle with a small amount of diesel fuel. ${ }^{4}$ This technology increases the power of the engine and increases LNG's fuel economy. The emissions benefits of LNG are similar to CNG: It has a $21 \%$ to $25 \%$ reduction in GHG emissions and produces lower levels of smog-forming emissions.

\section{Sources of Natural Gas}

Although CNG and LNG trucks can receive fuel from a natural gas pipeline, they may also be able to use renewable biogas. As a landfill's organic materials naturally decompose, they release methane (also known as biogas, or renewable natural gas). Many landfills burn or vent this gas, but if it is purified, it can be used as vehicle fuel. Even though the United States produces 27 billion cubic feet of landfill gas annually, there are only a small number of facilities using it to fuel vehicles. ${ }^{5}$ In contrast, Sweden uses biogas

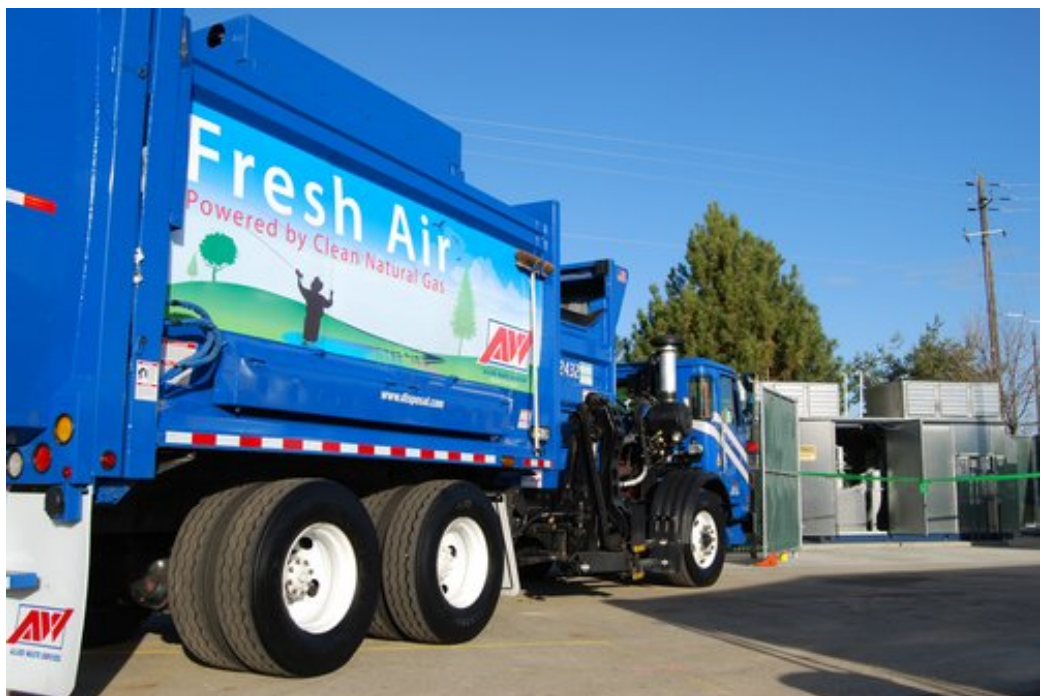
An Allied Waste refuse truck in Idaho fueled by natural gas. In 2009, the U.S. Department of Energy awarded funding to help the company introduce 24 natural gas refuse haulers into its fleet. Photo from Questar Gas, NREL/PIX 18287 to fuel more than half of its 11,500 natural gas vehicles. Because it is a renewable resource, landfill gas has $72 \%$ to $100 \%$ lower lifecycle GHG emissions than fossil-fuel based natural gas. The Solid Waste Authority of Ohio is one successful example. Its Green Energy Center uses 8\% of its methane gas to produce 250,000 gasoline gallon equivalents of $\mathrm{CNG}$ annually. Biogas is also produced from agricultural and animal waste and at wastewater sewage treatment plants. New recovery and clean-up technologies can now transform these waste products into valuable renewable natural gas.

\section{Considerations for Adopting Natural Gas}

Fleets considering natural gas vehicles need to evaluate a number of factors, including infrastructure, maintenance, training, and routing.

\footnotetext{
${ }^{4}$ NREL. Norcal Prototype LNG Truck Fleet. 2004.

${ }^{5}$ Argonne National Laboratory. Well-to-Wheels Analysis of Landfill Gas-Based Pathways and Their Addition to the GREET Model. 2010.
} 
Before fleets purchase natural gas vehicles, they must secure a steady supply of the fuel. A fleet can choose to build its own fueling station or contract with a fuel service provider who can build, operate, and/or maintain the station and roll the price into the overall cost of the fuel. The economics for each situation will differ depending on what kind of long-term pricing agreement is negotiated with the fuel supplier and local gas utility regulations.

Fleets considering natural gas vehicles also need to evaluate the compatibility of their garages and vehicle maintenance facilities. Many existing facilities will require modifications or upgrades. Older facilities that use open-flame or infrared heaters may need more expensive modifications.

Fleets must also determine whether they need to install fast-fill or slow-fill pumps. Fast-fill CNG systems can refuel a truck in roughly the same amount of time it takes to fuel with diesel (minutes), but they are more expensive. Slow- or time-fill systems can cost considerably less to build, but are only practical for fleets that are parked overnight or for several hours on a daily basis. The NREL Business Case for Municipal Fleets assumes fast-fill, because more vehicles can use the infrastructure, and it is most similar to what they are accustomed to with diesel. However, refuse trucks that are parked in a home based lot every night may be good candidates for a CNG time-fill system.

Before purchasing any vehicles, fleets should consider how they are going to be used. CNG vehicles, which typically have shorter ranges than LNG and diesel vehicles, may not be suited for the longest routes. All of a fleet's natural gas vehicles should start and end in the same location so that they can use the same infrastructure. Considering these factors beforehand will help fleets maximize their natural gas vehicle fleet.

Maintenance on $\mathrm{CNG}$ vehicles varies from fleet to fleet. $\mathrm{CNG}$ vehicles require some additional maintenance and parts (like spark plugs) compared to traditional diesel vehicles, but they also have fewer emissions control devices (e.g., exhaust filters and traps), helping to reduce operations and maintenance costs. In addition, some fleets are able to perform maintenance less often (i.e., longer oil change intervals and reduced waste disposal costs for used oil and filters). Working closely with the manufacturer, especially on a newer technology, can help lessen maintenance concerns and costs.

A fleet can help improve the transition to natural gas by providing its staff with additional training. Drivers must learn how to fuel the vehicles safely and may need new fueling or driving routines.

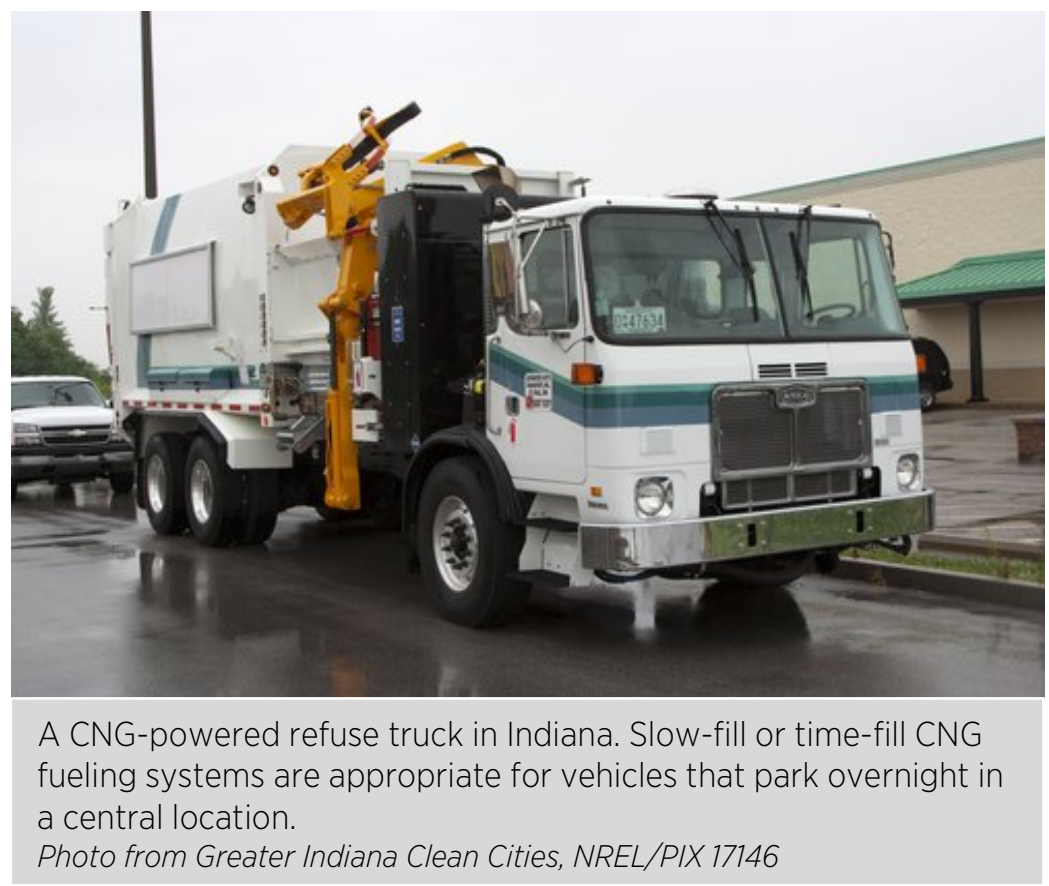


Maintenance staff may need to learn new schedules or obtain additional certifications. A welltrained staff reduces the need to rely on the dealership for repairs. It also gives drivers reliable contacts to call if they have questions or problems.

\section{Hybrid Vehicles}

\section{Types of Hybrid Vehicles}

Using advanced technology vehicles, such as hydraulic and electric hybrid trucks, can help a fleet reduce its petroleum consumption and emissions. Potentially, these technologies could also be combined with alternative fuels.

A hydraulic hybrid system captures about $70 \%$ of the kinetic energy that would otherwise be lost during braking. This energy drives a pump, which transfers hydraulic fluid from a lowpressure reservoir to a highpressure accumulator. When the vehicle accelerates, the

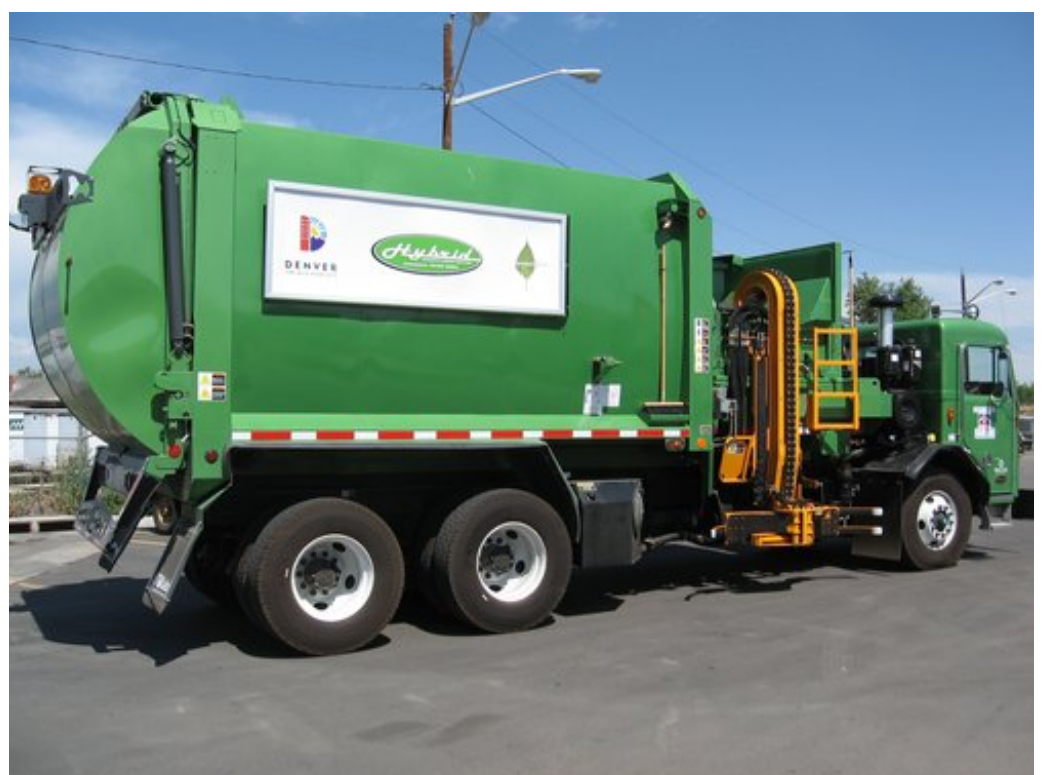

A hybrid hydraulic refuse truck in the City and County of Denver fleet. The truck utilizes hybrid launch assist technology to reduce fuel use on stop-and-go routes. Photo from Denver Fleet Management, NREL/PIX 17153 fluid in the high-pressure accumulator moves to the lower pressure reservoir, which drives a motor and provides extra torque. This power improves the vehicle's fuel economy by $25 \%$ to $30 \%$ compared to its non-hybrid equivalent. Because the system relies on frequent braking, the stop-and-go routes of refuse trucks are an ideal application.

Electric hybrid systems also capture energy from braking, but they store it in a battery pack. The batteries are largely used during the "launch," or acceleration, dramatically decreasing the amount of petroleum used and emissions produced.

\section{Considerations for Hybrid Vehicles}

Hybrid vehicles generally do not require new fueling infrastructure or changes to maintenance facilities. However, it is still helpful to consider their routing, vehicle availability, and training. Hybrid systems, both hydraulic and electric, do best in stop-and-go routes such as residential 
pick-up through city or suburban neighborhoods. Hydraulic hybrid vehicle models are currently available on the market and can be found in the Alternative Fuels and Advanced Vehicles Data Center's Heavy-Duty Vehicle Search (wWW.afdc.energy.gov/afdc/vehicles/search/heavy).

Electric-hybrid refuse haulers are not readily available. However, demonstration vehicles have been used in the past and may be available in the future. As with all new technologies, fleets using hybrids will need to provide their technicians with additional training.

\section{Other Fuels}

\section{$\underline{\text { Biodiesel }}$}

Biodiesel is another alternative fuel that refuse hauler fleets may want to consider. Biodiesel is domestically produced and nontoxic. Using a B20 blend (20\% biodiesel and $80 \%$ petroleum diesel) in a heavyduty engine produces $15 \%$ lower GHG emissions than petroleum diesel and reduces emissions of a number of other harmful pollutants (e.g., particulate matter, carbon monoxide, unburned hydrocarbons). ${ }^{6}$ In addition, biodiesel improves fuel lubricity and is less combustible than petroleum diesel. Because biodiesel must meet ASTM fuel

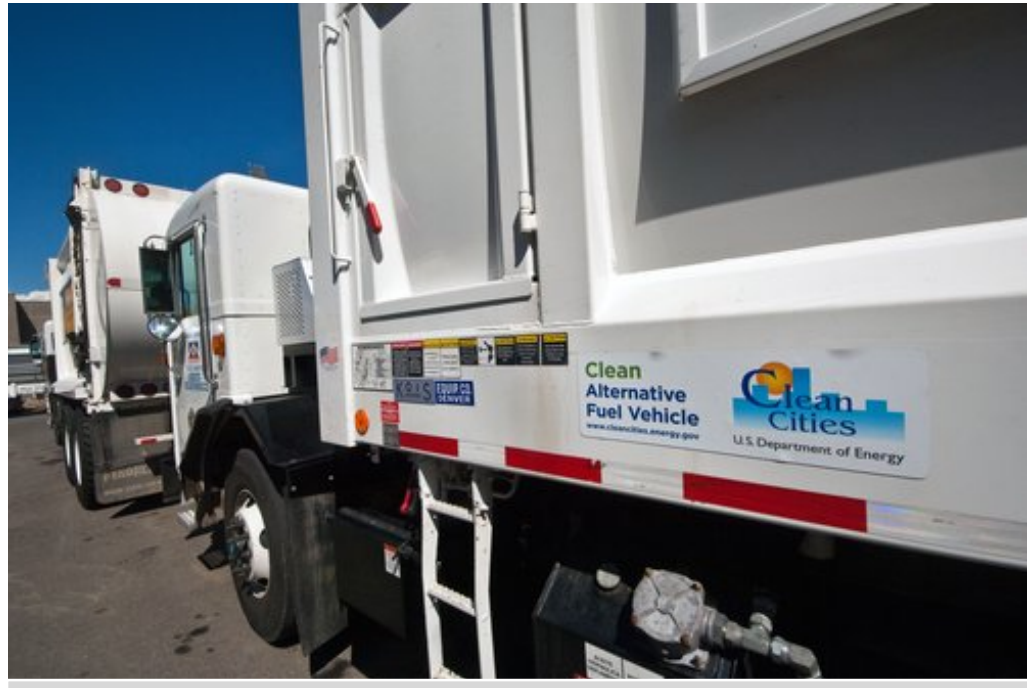

A refuse hauler fueled with $\mathrm{B} 20-20 \%$ biodiesel, $80 \%$ petroleum diesel. Biodiesel is a renewable fuel and produces lower levels of greenhouse gas emissions than regular diesel. Photo by Pat Corkery, NREL/PIX 18124 standards, fuel from reliable suppliers should be consistently of high quality.

Nearly all diesel vehicles can run on biodiesel blends up to B20 without modifications. However, operators should consult their vehicle and engine warranty statements before using any blend. Those who want to use biodiesel blends significantly above B20 should understand its cleaning effect and cold flow properties. Biodiesel can be more expensive than standard diesel fuel. There is currently a tax incentive of \$0.01/gallon per percent credit (e.g., 20 cents for B20), which expires in December 2011.

\footnotetext{
${ }^{6} \mathrm{AFDC}$ (http://www.afdc.energy.gov/afdc/fuels/biodiesel_benefits.html).
} 


\section{$\underline{\text { Propane }}$}

Propane is another option for a fleet looking to shift to alternative fuels. Propane, also known as liquefied petroleum gas, is nontoxic and domestically produced. It is the most popular alternative fuel in the world, and propane fueling stations are widely available. Propane stations are typically less expensive to install than natural gas stations are. Compared to gasoline vehicles, propane vehicles produce $21 \%$ to $24 \%$ lower GHG emissions, as well as lower levels of several other harmful emissions, including particulate matter, carbon monoxide, and oxides of nitrogen. ${ }^{7}$ The price of propane is often lower and less volatile than the price of diesel.

\section{Vehicle Deployment}

Fleets investing in alternative fuels or advanced vehicles have several ways to minimize their costs. Fortunately, the incremental cost between traditional and advanced or alternative fuel vehicles is shrinking. If a fleet is installing infrastructure, the Alternative Fuel Infrastructure Tax Credit can cover $50 \%$ of the cost of installing a station. In addition, a $\$ 0.50 /$ gallon tax incentive is available for all forms of natural gas fuel used to operate a motor vehicle. Some states, such as California and Texas, also have substantial incentives.

Innovative funding agreements can also help fleets reduce lifetime costs. In San Diego, Pacific Gas \& Electric paid for the incremental cost of a fleet's LNG trucks because the decrease in truck emissions offset the emissions produced by a new electricity generator. Fleets can minimize their CNG costs by negotiating a fixed-price contract that guarantees the price of CNG cannot rise above the price of diesel.

Considering the many factors involved in using alternative fuels or advanced vehicles before investing in them is the best way to save time and money. Although starting with a few trucks can allow a fleet to "try out" a technology, it can result in a longer payoff time than investing in a large fleet. If your fleet is interested in adopting these technologies, work with your local Clean Cities coordinator to obtain more information and connect with similar fleets.

\footnotetext{
${ }^{7}$ AFDC (http://www.afdc.energy.gov/afdc/vehicles/emissions_propane.html).
} 


\section{Fleets Interviewed}

Casella Waste, Rutland, Vermont

City of Ann Arbor, Michigan

City of Mesquite, Texas

City of Oklahoma City, Oklahoma

City of St. Louis, Missouri

City of Tulsa, Oklahoma

City of Culver City, California

Maggio Sanitation, Yaphank (Long Island), New York

New York City Department of Sanitation, New York

Allied Waste, Boise, Idaho

\section{Resources}

Business Case for Compressed Natural Gas in Municipal Fleets, NREL:

http://www.afdc.energy.gov/afdc/progs/view_citation.php?10676/CNG

Refuse Hauler Fleet Experiences, NREL:

http://www.afdc.energy.gov/afdc/fleets/refuse haulers experiences.html

Greening Garbage Trucks: Trends in Alternative Fuel Use, INFORM:

http://www.informinc.org/ggt.php

\section{Costs and Emissions ${ }^{8}$}

\begin{tabular}{|l|l|l|l|l|l|}
\hline $\begin{array}{l}\text { Vehicle } \\
\text { Type }\end{array}$ & $\begin{array}{l}\text { Differential } \\
\text { Vehicle Cost }\end{array}$ & $\begin{array}{l}\text { Infrastructure } \\
\text { Cost }\end{array}$ & Fuel Cost & $\begin{array}{l}\text { Petroleum } \\
\text { Reduction }\end{array}$ & $\begin{array}{l}\text { GHG Reduction } \\
\text { (Compared to Diesel) }\end{array}$ \\
\hline CNG & $\$ 30,295$ & $\begin{array}{l}\$ 1,535,250 \text { (for } \\
25 \text { vehicles) }\end{array}$ & $\begin{array}{l}\$ 1.93 / \text { DGE } \\
\text { (diesel gallon } \\
\text { equivalent) }\end{array}$ & $100 \%$ & $21-26 \%$ \\
\hline LNG & $\sim 56,000$ & $\begin{array}{l}\$ 1.5 \text { (small) }-3.0 \\
\text { mil. (large) }\end{array}$ & $\begin{array}{l}\$ 1.50-2.00 / \\
\text { DGE+ (varies } \\
\text { with price of } \\
\text { CNG) }\end{array}$ & $100 \%$ & $16-25 \%$ \\
\hline $\begin{array}{l}\text { Landfill } \\
\text { biogas }\end{array}$ & $\begin{array}{l}\text { Same as CNG or } \\
\text { LNG }\end{array}$ & $\begin{array}{l}\$ 10.5-\$ 17.5 \\
\text { million+ }\end{array}$ & N/A & $100 \%$ & $72-100 \%$ \\
\hline $\begin{array}{l}\text { Hydraulic } \\
\text { hybrid }\end{array}$ & $\$ 39,182$ & N/A & $\begin{array}{l}\$ 3.07 / \text { gallon } \\
\text { (diesel) }\end{array}$ & Up to 30\% & Up to $30 \%$ \\
\hline $\begin{array}{l}\text { Electric } \\
\text { hybrid }\end{array}$ & $\begin{array}{l}\$ 315,000 \text { (Pre- } \\
\text { production } \\
\text { prototypes) }\end{array}$ & N/A & $\begin{array}{l}\$ 3.07 / \text { gallon } \\
\text { (diesel) }\end{array}$ & Up to 30\% & Up to 30\% \\
\hline
\end{tabular}

Table Sources and Notes:

- CNG vehicle and infrastructure costs are from the NREL Business Case for Compressed Natural Gas in Municipal Fleets.

\footnotetext{
${ }^{8}$ As of fall, 2010
} 
- LNG vehicles and infrastructure costs are estimates from American Recovery and Reinvestment Act projects (South Coast Air Quality Management District, San Bernardino Associated Governments, Connecticut Clean Cities Future Fuels Project). LNG vehicle costs may vary due to limited market availability. LNG infrastructure costs will vary based on facility size and other factors.

- Landfill gas infrastructure cost estimates are based on full-scale projects (Altamont, CA; DeKalb County/Metropolitan Atlanta Alternative Fuel and Advanced Technology Vehicle project, supported by the Recovery Act). Demonstration projects may be significantly less; the Solid Waste Authority of Central Ohio reports its demonstration project cost about $\$ 5$ million. CNG projects are typically less expensive than LNG projects. If the project is installed when a landfill is installed, it may be less expensive. Other biogas projects will have different costs depending on size and circumstances.

- Hydraulic hybrid vehicle cost is based on pricing from the CEC Michigan Green Fleets Initiative Recovery Act project.

- Electric hybrid vehicle cost is based on an interview with the New York City Department of Sanitation fleet manager about their prototype vehicle.

- All fuel costs are as of October 2010 from the Alternative Fuel Price Report (prices may differ from geographic location to another). 


\section{NOTICE}

This report was prepared as an account of work sponsored by an agency of the United States government. Neither the United States government nor any agency thereof, nor any of their employees, makes any warranty, express or implied, or assumes any legal liability or responsibility for the accuracy, completeness, or usefulness of any information, apparatus, product, or process disclosed, or represents that its use would not infringe privately owned rights. Reference herein to any specific commercial product, process, or service by trade name, trademark, manufacturer, or otherwise does not necessarily constitute or imply its endorsement, recommendation, or favoring by the United States government or any agency thereof. The views and opinions of authors expressed herein do not necessarily state or reflect those of the United States government or any agency thereof. 


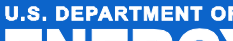

ENAROY

Energy Efficiency \&

Renewable Energy
EERE Information Center

1-877-EERE-INFO (1-877-337-3463)

www.eere.energy.gov/informationcenter

DOE/GO-102011-3297 • September 2011

Printed with a renewable-source ink on paper containing at least $50 \%$ wastepaper, including $10 \%$ post consumer waste. 